\title{
Use of Device Problem
}

National Cancer Institute

\section{Source}

National Cancer Institute. Use of Device Problem. NCI Thesaurus. Code C63318.

Problem associated with failure to process, service, or operate the device according to the manufacturer's recommendations or recognized best practices. 